\title{
PROBLEMATIZING PREVALENCE OF RASAIN THE PLAYS OF MAHESH DATTANI
}

\author{
Dr. Anshu Surve \\ Ms. Garima Hariniwas Tiwari
}

\begin{abstract}
Natyashastriya theory of Rasa is a spirit so abstract that can only be suggested, not described in any work of visual, literary or performing art. Rasabhasa, a concept from Bharata Muni's Rasa theory, alternatively nomenclated as a semblance of Rasa interestingly appearsparallel to Rasa but is not Rasa. Bharatmuni reiterates the relishing of Rasa or Rasabhasa from a conditional amalgamation of Bhava (emotions), Alambana Vibhava (protagonist), Uddipan Vibhava (environment) and Vyabhicharibhava (transitory emotional feelings) in the protagonist i.e. the one who leads (NayatiItiNeta). The conditionality isfurther enunciated emphasizing that not all protagonists relish Rasa or Rasabhasa distinctively in a dramatic performance. Modern plays with their stark distinctions from the ancient Indian plays like Abhigyanshakuntalam portray multilayered characters dealing with the questions of identities in various spatialities and temporalities at a glance do not seem insinuated with the characteristics underpinned in Natyashastra. These distinctions and coming away from the thematic contextualization of ancient Indian plays enshrouds the idea of Rasa Relish. Dattani's On a Muggy Night in Mumbai and Seven Steps around the Fire explicitly raise gender and identity issues of LGBT community, in dealing with their thematic structure and characterization reveal relishing of Rasa or Rasabhasa. The paper critically problematizes the translational affinities between Rasa and Rasabhasa, also aspires to explore two plays by drawing on the concept of Rasabhasa. (Re) interpreting Rasa and Rasabhasa in the context of modern LGBT plays is the central premise of this research paper.
\end{abstract}

Keywords:LGBT, Rasa, Rasabhasa, Gender Studies, Indian English Drama. 


\section{Introduction}

\section{Dr. Anshu Surve \& Ms. Garima Tiwari / Page 526-543}

Among the many notions about the modern Indian English drama, one significantly draws line of demarcation from the ancient Indian drama in the sense that the modern Indian English drama does not exhibit congruence with certain elements and features of classical (Sanskrit) drama as well as theatre. Mahesh Dattani being the vanguard of modern Indian drama portrayed modernity in tangentiality with Mahesh Elkunchwar through characters and language distanced from traditional drama in Sanskrit, revealing various untouched dimensions and trajectories of the urban spaces with all its anxieties, conflicts, angst, questions of identity, precarity, prominent in his compositions - Final Solutions, Dance Like a Man, On a Muggy Night in Mumbai, The Big Fat City, Seven Steps around the Fire. An unwelcoming response towards On a Muggy Night in Mumbai, from the Heterosexuals as well as Homosexuals of society left Dattani puzzled, and a tale of hijra Community beset with realistic challenges of a eunuch's life and society's impenetrable attitude towards them in Seven Steps around the Fire are the compass to (re) interpret Rasa and Rasabhasa. The main premise of this paper is rooted in a debatable idea, whether these plays, based on the lives of men and women in present times, when analyzed through the critical lenses of Rasa theory, which might seem as an attempt (questionable though) to bring two poles, two binaries on one forum, evoke Rasa or are instrumental in evoking Rasabhasa. Evoking of Rasa and Rasabhasa in the plays foregrounded in the socio-cultural, political and legal contexts of the LGBT is permeated with multifarious research questions - What are the historical and evolutionary interpretations of is Rasa and Rasabhasa; How is Rasa different from Rasabhasa?; How do the LGBT plays of Mahesh Dattani engage with Rasa experience or semblance of Rasa?; and the paper attempts to find answers to these questions.

\section{Indian Drama: A Brief History}

'Indian Drama' cannot be restrained into a definition as it encompasses the entire gamut of Indian culture - the myths, the folklores, the history and the ethos of the nation. 'Modern Indian English Drama' has evolved over the ages for not to be compartmentalized, promising insightful reflection of the present-day life with all its simple complexities and complex simplicities. The history of Indian drama can be traced back to the Vedic era where plays had religious bearings, the fervor of faith, beliefs and their influence in life. It is widely agreed that akin to the English Morality and Miracle plays, Indian drama is also substantially religious in nature; Indian drama was set in motion with a performance in the court of God, when Gods led by Indra solicited Brahama to induce something pleasing and gratifying to 
both the senses - eyes and ears. A belief is that the 'Indradhwaja Mahotsava' was celebrated to commemorate the joyous occasion of the creation of the fifth Veda - the Natyaveda, the narration of this unique event flushed with dance and music is found in the Bharata Muni's encyclopedic work Natyashastra. The prime contributors of Indian drama, known for borrowing and popularizing plots and stories from history (now ancient history), folk legends, epics, and wars, full of aesthetic sublimity are Mahakavi Kalidasa, Bhasa, Shudhraka, Harsha who have penned emotions, experience, psychology, culture, traditions and beliefs in their rich dramatic works. The trajectory of Indian performative and stage art in the states of Kerala, Tamil Nadu, Uttar Pradesh, Andhra and Gujarat was predominated by Sanskrit plays till the $15^{\text {th }}$ century, thereafter, continuous and consistent foreign invasions curtailed the prosperity of performative art and culture. Drama emerged from its dormancy in the form of People's Theatre, popularly known as Loknatya in the $17^{\text {th }}$ century and flourished in the form of Bhavai of Gujarat, Nautanki of North India, Raas of Rajasthan, Tamasha of Maharastra, Bhangra of Punjab with the Brechtian reformative impulse. The roots of Dance Drama Loknatya can be traced back to Natyashastra (200BC) where Bharata Muni made a passing reference to Nrut and Nrutya, Dhanamjaya conceptualized and theoretically located these two terms in his Dasharupakam, according to which Nrutya is based on Bhava (emotion) and Nrut is based on Laya and Taal (rhythm). Drama to lyrical performances of Ramayana, Krishnalila, Devi Bhagwata, PrithvirajRaso by Chandra Bardai and Padmavat by Malik Muhammad Jayasi are distinctive examples of Nrutya whereas Raas and Garba are based on the performative postulates of Nrut. The spread of Indian freedom movement in the nooks and corners of the nation can be contributed to these Loknatya.

Theatre in India took a modernist turn during the British rule when the modern proscenium theatres dawned on Indian soil with Calcutta and Bombay being the prominent centres. A Dramatic Performances Act - 1876 was implemented to stop the Indian theatrical and street performances, encouraging freedom struggle against the British rule in India. Dramatic performances known for their poetical excellence, thematic variety, symbolism and morality contributed significantly in the growth of Indian English drama where Sri Aurobindo's Vasavadutta, Rabindranath Tagore's Chitra, and Harindranath Chattopadhyaya's Window were meant to be read, not performed. Later on, Vijay Tendulkar, Girish Karnad and Mahesh Dattani in their dramas (to be performed) voiced the unheard voices of anxiety,subjugation and marginalization, caste and class discrimination, problematizing soci0-political actualities deeply permeated in the fabric of the nation,brought about a reformative turn paving way for completely new age themes ofgender, identity, child abuse, precarity etc. foregrounded in the 
critical domains of post colonialism, Marxism, Feminism, Modernism and Realism. The modern Indian English drama, especially Mahesh Dattani's plays sketch the complexities of Indian society on the canvas of a stage with all the shades dismissing the traditional character portrayal (belonging to royalty or nobility) on the grounds of the Aristotelian norms or the postulates of Indian Natyashastra thus, humanizing and democraticising the textual and performative characterization. Since then, modern Indian drama has augmented in terms of technological advancements, relevant furnishing, lights and backdrop serving as ambience on stage entirely in contrast to the theatrical practices of demonstrating the shifting of scenes either through dialogic representations or placard formations on a unidimensional stage.

The literary trajectories permeated with the critical percepts from the beginning theory to either the death of theory or the death of the author, from Freud's Psychoanalysis, Weber's Industrial Isolation, Maslow's Need Hierarchy theory to Homi Bhabha's Hybridity, Gayatri Spivak's Can The Subaltern Speak to Sudhir Kakkar's Indian Psyche have induced a change in the ways of thinking which echoes in the literary works. In the pursuit of interrogating the complexities of human life on the lines of these critical discourses, Rasa theory with all its simplicities has got decimated to a mere application to texts addressing the east-west binaries or to bridge the philosophical divide of the west and the global south. This decimationseems to reflect on the theory of Indian aesthetics being obsolete but, it also cannot be denied that present is, if not the product but an extension of the past and establishing the relevance of the poetics of Indian aesthetics offers a fresh interpretation of not only the theory itself but also an opportunity to re-comprehend the Rasa discourse in the light of modernity as well as modernism in English literature.

\section{Rasa Theory: An Overview}

It has been observed that Rasa theory of Indian Aestheticserroneouslytranslated/interpreted as a juice, a flavor, emotions, feelings, sentiments, taste, sap, aesthetic mood, essence, fluid, due to its versatility and significance in the present world.An equivalent of Rasa doesn't exist, Rasa cannot be translated or interpreted or transliterated due to its cultural rootedness. Natyashastriya theory of Rasa is a transcendental pleasure, a spirit that can only be suggested, not described. Rasarelishes when one leaveshis/herindividual, egoistic, pragmatic persona of modern, self-centered world and assumes an impersonal contemplative attitude free from all craving, striving and external necessity.Rasa can be understood as a dynamic experience among the character, an artist(actor/performer), and an audience; Rasahas 
travelled a remarkable journey starting from the emanation of the word to its acceptance as a substantial and universal theory, to ascertain its meaning in each era.

As a fundamental concept andRasa as a word is believed to be coined for the first time in the Taitariya Upnishadaas- "रसोवैस:रसंह्येवायंलब्धवानन्दीभवति" (Being means of eminence pleasure, Rasa and soul are equal) (1985), signifying that Rasa and pleasure are coupled, Rasa is a charioteer of eminence pleasure which is not easy to attain in this materialistic, multi-dimensional, capitalist, modern, vibrant world. Historically decisive treatise - the Agnipurana penned by Vyasa classifies Rasa, as -“ वाग्वैदाधप्रधानेsपिरसएवात्रजीवितम्" (Though the Kavya is full of beauty of language, but Rasa is the reason behind aliveness of Kavya) (1966), Rasa has been characterized as nectar(ethereal in nature) of literature.

A formula (Sutra) of Rasa, acknowledged as Rasasutra in the $6^{\text {th }}$ chapter of an encyclopedic treatise -Natyashastra provides absolute perception of Rasa “विभावानुभावव्यभिचारिसंयोगात्रसनिष्पत्तिः".The aesthetic relish is produced (Rasanishpattih) by a combination of the determinants ((Vibhava), consequents (Anubhava), and transitory states or fleeting emotions (Vyabhicharibhava)) (1971), which has been further re-constructed by successors of Bharata Muni in their interpretations of Rasa or Natyashastra. Bhatt Lollata, the successor of Bharata Muni defines निष्पत्ति as उत्पत्ति in interpreting Rasasutra and suggests that Rasa relishes in the characters like Ram and in the actor; conceivably, it is a source of pleasure and the final stage of emotions and feelings lies in the literal characters and actors. Shree Shankuk, a follower of Bhatt Lollata adds the theory of Chitraturagnyayato relish Rasa. One of the path breaking scholars - Bhatta Nayaka argued that Rasa does not only relish in a character, but relishes in the audience along with the actor and the character, a satisfactory and absolute argument, as the earliest drama was performed to entertain and please the audience (Gods). Bhatta Nayaka exhibited that Rasa cannot be expressed; it can only be felt. Abhinavgupta Padacharya, a believer of Dhwani and a profounder of अभिव्यक्तिवाद disseminated forever existence of Rasa in the heart of humans as Sthayibhava, which relishes as Rasa through the process of साधारणीकरणin audience.

After Abhinavgupta, there has not been a significant theoretical contribution to expand the horizons of Rasatheory; no paradigm shift seems to visibly mark the Rasa theory. The scholars and authors, such as Dhanamjaya, Vishvanatha, Mammata, Jagganatha, Ramchandra Gunchandra have all-inclusively rewritten theory of Rasa in their respective historically significant and individually indifferent treatises. It is widely agreed as well as explicitly visiblethat there came stagnation in the development of Rasa as a theory, no valuable 
absorption was brought after Abhinavbharti of Abhinavgupta, the next-in-line scholars have discussed Rasawith no groundbreaking historical, chronological, semantic, psychological underpinnings.

For a considerable period of time, Natyashastra and theory of Rasa developed in the form of a culturally and literary acceptable translation in various regional languages in India. In premodern and modern age, the scholars and researchers of distinct disciplines, such asPerforming Arts, Literature, Medicine, Computer and Civil Engineering have tried to interpret Rasa in their owntrajectories catering to the need of time and politics of closely associated subjects. Availability of scholarly articles on Rasa theory in number of disciplines, languages, contexts, subjects, indicates recognition and relevance of Rasa theory in the contemporary literary and theoretical world: A Professor of Columbia University - Sheldon Pollok's A Rasa Reader, a translated compilation of several prevalent Indian treaties/texts and scholarly interpretations available on Rasa with its limitations though, brought around the interest in Rasa Studies. The other renowned treatise in consideration is Dr. Nagendra's Rasa Siddhanta, a magnificent treatise with valuable insights, flooded with contributions and interpretations of Rasa in the $20^{\text {th }}$ century world. An application of Rasa theory in a Chinese text, Novels of Hardy, Poems of Tennyson, and Novels of R.K. Narayan and so on is a popular practice, making attempts to understand and demonstrate relevance of Rasa, hence, contemporizing it in an absolutelydiverse era far distinct from the era of Natyashastradeancientizing Rasa, Rasa Experience and Rasa Relish.

Shringara, Hasya, Raudra, Karuna, Veera, Adbhuta, Bhayanaka, Bibhatsa and Shanta are the nine Rasa; except Shanta, other eight are predominant in drama, accumulation of Vatsalya and Bhaktias Rasa in the inimitable list of Nine Rasa from the original Shringara Rasa occurred with the need and demand of time, at the time of Bhakti Movement in India.

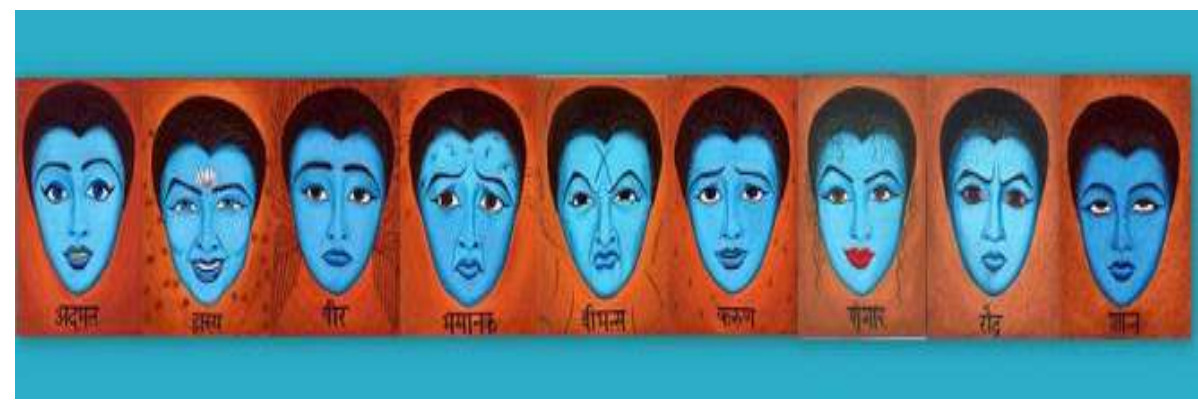

Figure 1: Nine Rasa

Rasa cannot be defined or understood in an isolation because of its enormity and close association with physiological and psychological framework, such as - Sthayibhava, Anubhava, Vibhava, Vyabhicharibhava, Alambanavibhava, Uddipanavibhava, Satvikbhava, 
etc. Male and female protagonists are Aalambanavibhava; an isolated place, wonderful atmosphere, beautiful river bank, or garden are examples of Uddipanavibhava with reference to Shringara Rasa. Anubhavais perceived because of Aalambana and Uddipanavibhava. Anubhava appears to be a physical activity, whereas Satvikbhava is a plausible mental activity. Stambha(Paralysis), Pralaya(Fainting), Romancha(Thrill), Sweda(Sweating), Vaivarnya (Change of Color), Vepathu(Kampa) (Trembling), Ashru(Weeping) and Vaisvarya (Change of Voice) are eight Satvikbhava.Vyabhicharibhava are 33 in number, such as Nirveda (Discouragement), Glani(Weakness), Shanka (Apprehension), Shrama(Weariness),Dhruti(Contentment),Jadta(Stupor),Harsha(Joy), Dainya(Depression), Ugrata(Cruelty), Chinta(Anxiety), Trasa(Fright), Asuya(Envy), Amarsha(Indignation), Garva(Arrogance), Smruti(Recollection), Marana (Death), Mada(Intoxication), Supta(Dreaming),Nidra(Sleeping), Vibodha(Awakening), Vreeda(Shame), Apasmaara(Epilepsy), Moha(Distraction), Mati (Assurance), Aalasya(Indolence), Aavega(Agitation), Vitrka(Deliberation), Avahittha(Dissimulation), Vyadh(Sickness), Unmaada(Insanity), Vishaada(Despair), Aautsukya(Impatience), Chapalata(Inconstancy). Sthayibhavas, also known as permanent and durable states of humans, Sthayibhavas are always, already present in human and relish as Rasa, Rati (love) for Shringara, Hasa (mirth) for Hasya, Utsaha (energy) for Veera,Smaya, Vismaya (astonishment) for Adbhuta, Krodha (anger) for Raudra, Shoka (sorrow) for Karuna, Bhaya (fear) for Bhayanaka, Jugupsa (disgust) for Bibhatsa and Nirveda(tranquility) for Shanta are Sthayibhavas.

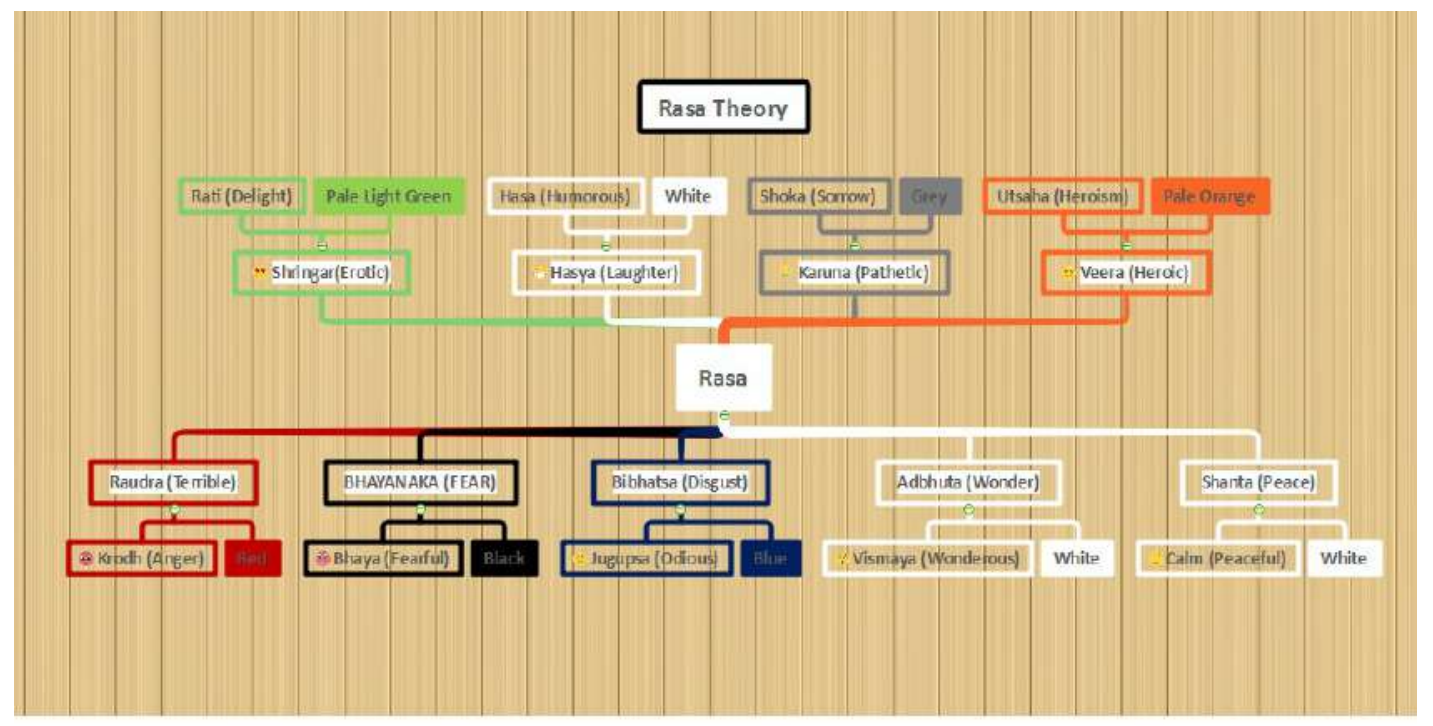

Figure 2: Rasa, Sthayibhava, Deity, Colour 
Rasa, a psychologically important concept has associated deity and a colour, as shown in the diagram. Apart from Sri Krishna, the Supreme God, all other gods and goddesses are entities of the guna ranging from divine (sattvic), semi-divine (rajasic) or evil (tamasic). Colours like green, orange, black, blue, white, red, etc. is a charioteer of an associated Rasa in the form of Alambanavibhav and Uddipanavibhav. Thus, Rasatheoryhas multipledirectly or indirectly associated theories with it; a debatable theory of Rasabhasa is one of them.

\section{Rasabhasa: A Debatable Theory}

A Sanskrit multifariousword consisting of two terms - Rasa and Aabhasais termed as Rasabhasa - a semblance of Rasa, at a fleeting look, Rasa and Rasabhasa cannot be differentiated effortlessly, especially with reference to modern Indian English drama which has various modern characters (homosexuals) as protagonist, bizarre but relatable themes unlike ancient Indian drama. The Mirage is a semblance of water but actually it is not water, in the same way Rasabhasa appears to be Rasa but actually it is a semblance of Rasa. In the $6^{\text {th }}$ chapter of Rasa theory, Bharata Muni (200 BC) subsequently conceptualizes Rasabhasa in Natyashastra, but somehow the term and concept of Rasabhasa was not reflected upon and discussed by scholars, except Abhinavgupta, Mammata and Jagganatha, there has been a paucity of critical scholarly work on Rasabhasa.

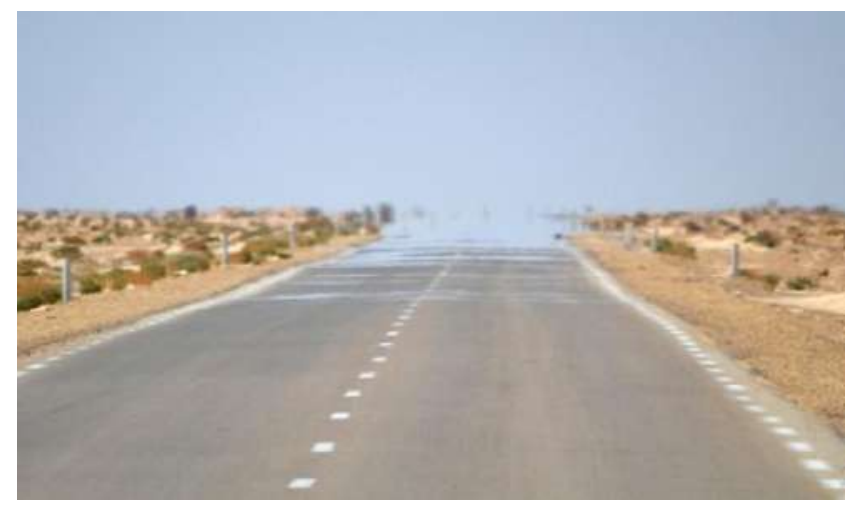

Figure 3: Mirage

Rasabhasais often discussed in the context of BhaktiRasa in the contemporary world, Rasabhasa in Bhakti signifies semblance of Bhakti Rasa, rather than aesthetic rapture of Rasa because the experience is not related to God, i.e. When Narada (Bhakta) saw two parrots in Vrindavan reciting Vedanta he was astonished (Adbhuta), but because his astonishment was not in relation to Lord Krishna, it is a source of Rasabhasa. It is believed that when demons or comic characters appear in Krishna-lila, Rasa such as laughter (Hasya), fear (Bhayanaka) relishes in an ordinary person, only devotees can experience Bhakti Rasa. 
A conditional coalesce of Vibhava, Anubhava, Vyabhicharibhava, Satvikabhava and Sthavibhava, relishes Rasa, otherwise it results in Rasabhasa. To distinguish Rasabhasa from Rasa,immaculate perceptive of Sthayibhava, Anubhava, Vibhva (Alambana and Uddipana), Satvikabhava and Vyabhicharibhavais indispensable, a knowledge of the physical or mental states of humans. Rasabhasa patently based on impropriety of Alambanavibhava (male or female protagonist) of drama. Propriety or impropriety is contextual and keeps changing with time, and place as asserted by Dr. Nagendra (2019), which can also be modified with culture, tradition, person, education, background, etc in the modern and postmodern, open, uncertain world. With the legalization of LGBT in India, homosexuals have been considered as a part of the society; whether characters of LGBT community can relish Shringara Rasa in the literature and considered propriety for other Rasa is one of the central questions of this research paper.

\section{On a Muggy Night in Mumbai and Seven Steps around the Fire: The Narrative}

According to Stephen Bruckner of The New York Times, Mahesh Dattani is 'a canny and facile writer' who is considered to the first Indian English playwright and a recipient of the Sahitya Akademi Award. Dattani's writing echoes the themes of the present day like gender and religious issues, sexuality and similar related subject matters as evident in his stage plays, screen plays and radio plays which are of utmost importance to contemporary urban India without diverging from the "classic concerns of world drama" which are personal and moral choices apart from human relationships. Dattani's composition includes stage plays, screenplays and radio plays, in which his craft of projecting social reality and related issues has been used. Dattani's group was founded in 1984 and the first and foremost play was Where There's A Will. Mahesh Dattani has produced brilliant masterpieces such as Tara, Bravely Fought the Queen, Final Solutions, Dance Like A Man, On A Muggy Night In Mumbai, Thirty Days in September, Where did I Leave My Purdah?, Seven Steps around the Fire and several others out of which some are critically-acclaimed. He has transformed the urban theatre of India with his dramatic vision and skills. Dattani believes in the philosophy of reviving the empathy in humans with his work. Alyque Padamsee, a prominent theatre persona and a recipient of Padma Shri epitomizes Dattani as "a playwright who gives 60 million English-speaking Indians an identity".

On a Muggy Night in Mumbai (1998), the first Indian play about homosexuality, deals with the acceptance of homosexuality with Mumbai city as its backdrop, on the other hand Seven Steps around the Fire (1998) is a protest play against the social exclusion of the hijras. Both 
the plays exhibit Mahesh Dattani's skill of dealing with challenging LGBT (Lesbian, Gay, Bisexual and Transgender) issues falling under the category of gender issues. Indian (English) writers (playwrights, poets, novelists) who used to think twice before writing and possibly still require a lot of guts to compose significant literature on the LGBT theme, whereas Mahesh Dattani writes and stages two plays in the year 1998, the plays with unconventional protagonists (not as proposed in Natyashastra), fighting for their rights directly or indirectly in the heterosexual (so-called normal) society despite of belonging in LGBT community.

\section{On a Muggy Night in Mumbai}

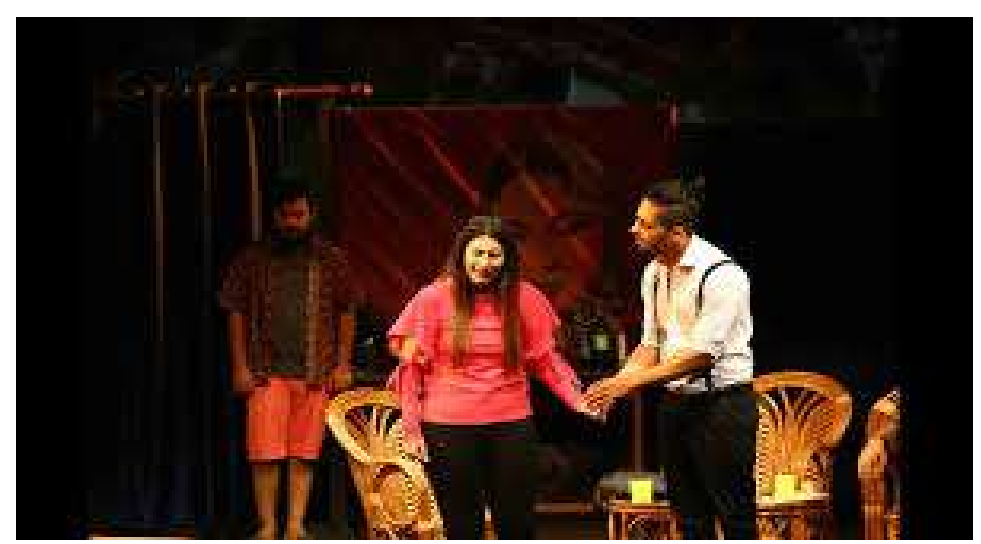

Figure 4: Stage Performance ofOn a Muggy Night in Mumbai

On a Muggy Night in Mumbai has been the first Indian drama, dealing with homosexuality explicitly on the Indian stage with the theme of homosexual love and vulgarity among the youths in a materialistic present world. The protagonists - Kamlesh and Prakash are passionate lovers, Prakash is ashamed of homosexuality, so he accepts life of a heterosexual and falls (or pretends to be) in love with Kamlesh's sister Kiran. On the other hand, Kamlesh's (who still loves Prakash) sexual needs are being fulfilled by Sharad, incidentally, Prakash once again enters in the life of Kamlesh as a lover of his sister Kiran. When Kiran (as a heterosexual) comes to know about homosexual relationship of Kamlesh and Prakash, she shows all compassion for homosexual relations.

\section{Seven Steps around the Fire}




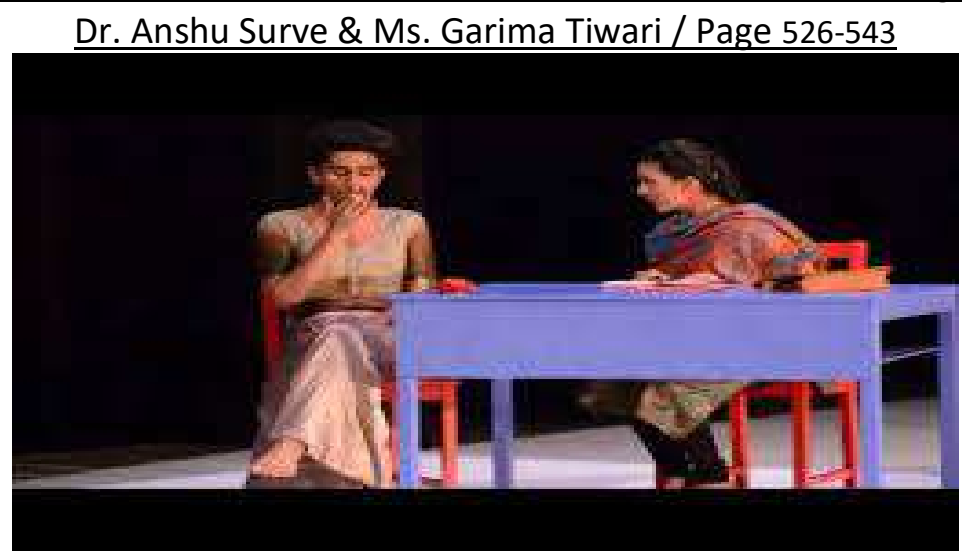

Figure 5: Stage Performance ofSeven Steps around the Fire

Seven Steps around the Fire revolves round an enquiry about the murder of Kamala, a beautiful Hijraby Anarkali. A transgender is not allowed to marry (take seven steps around the fire) in the society, the seven steps around the fire (a marriage) of Kamala with Subbu (a son of a Minister) results in her murder, an evidence of their marriage, the fire turns in Kamala's destruction. Uma, a research scholar and a wife of a Chief Superintendent of Police, a daughter of Vice Chancellor and a daughter-in-law of a DSP uncovers the truth behind a brutal murder in the city's hijra community.

\section{Rasa and Rasabhasa Theory based Analysis}

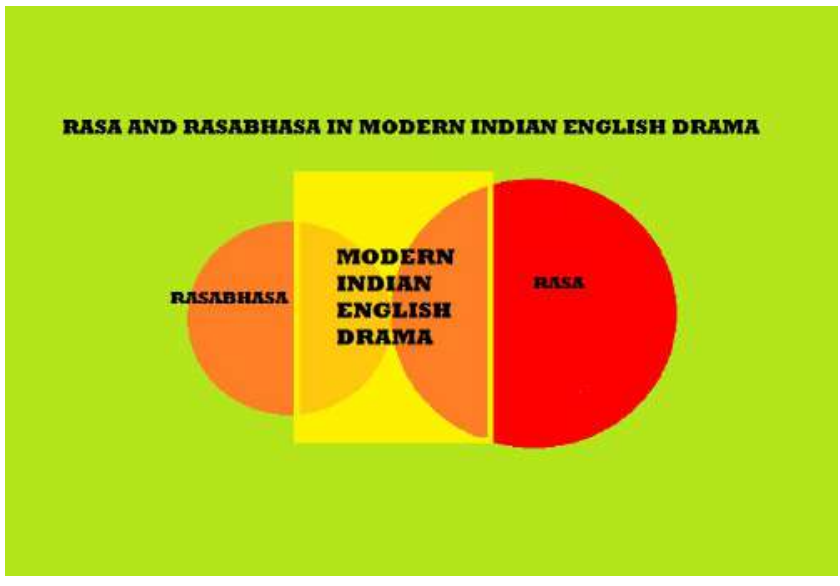

Figure 6: Rasa and Rasabhasa in the Modern Indian English Drama

According to dramaturgical rules of Natyashastra, plot and characters of a drama determines Rasa (Muni, 1971), the ancient Indian drama projected selective best types of characters as a protagonist to relish particular Rasa (as depicted in Natyashastra), but Bharata Muni has not referred to transgender as a protagonist, despite of presence of transgender in that era. On the other hand, Mahesh Dattani, the modern Indian playwright, in his plays deal with modern 
characters and themes, and life of the character of LGBT community (Homosexuals) is discussed in detail. According to Indian Aesthetics, the protagonist is one who leads (NayatiItiNeta), signifying that a leading character or a protagonist of the drama should have leadership quality, male/female protagonist should be an ideal person, only specific kind of protagonist can evoke and relish determined Rasa, i.e. Bheem relishes Veera Rasa, Krishnaevokes Shringara Rasa, Durvasa sage raises Bhayanaka Rasa. The protagonist is synonymous to Alambanavibhava, an impropriety of which leads to Rasabhasa, whereas propriety or impropriety is a subject to change according to time and society.

Following rules of Rasa theory, in the context of Shringara Rasa - Sthayibhava is Rati, Alambanavibhava is male and female protagonists (characters), Uddipanavibhava is background of a garden and Anubhava is an experience of watching male and female characters in the garden. Both of the plays - On a Muggy Night in Mumbai and Seven Steps around the Fire by Mahesh Dattani's characters are in deviation from the list of the characters mentioned in the category of protagonist in the Natyashastra. Even after legalization and acceptance of LGBT community in India under the section 377 of IPC, whether homosexuals and transgender can be the protagonist in the context of Rasa theory is a debatable question, an answer of that lies in a textual study of On a Muggy Night in Mumbai and Seven Steps around the Fire.

Kamlesh and Ed (homosexuals) are sitting in the garden and a conversation of love between them (or Kamlesh and Sharad) can be a source of Shringara Rasa for homosexuals, but it may relish Rasabhasa or Hasya Rasa or Bibhatsa Rasa in the people of different sexual orientation as Dattani rightly discuss people's response to the play in his Me and My Plays“On a Muggy Night in Mumbai was received with dismissal mostly. ... ... Most people chose to ignore it completely, as if they had never watched it." (Dattani, 2014, p.36)

i.e $e^{1}$ -

"Kamlesh: Every Single Word

Ed: Let me hear your story.

Kamlesh: No. not tonight. Hold my hand.

\section{Ed: Come closer...closer.}

Kamlesh: If only they could see how beautiful we are together.” (Dattani, 2000, p.81)

Similarly, Subbu's love for Kamla, a beautiful hijra can't be a source of Shringara Rasa for heterosexuals. 
i.e $e^{2}$.

“Subbu: I am leaving you all! You can’t keep me away from Kamla.” (Dattani, 2000, p.39)

In such situations, which Rasa will be relished in an audience? is a question. When it comes to aesthetic experience of Shringara Rasa, can such (LGBT) characters evoke Rasa is a question, an answer of which lies in a theory of Rasabhasa. Either Rasa or Rasabhasa relishes at a time from the Sthayibhava, Rasa and Rasabhasa cannot be relished together in a person but a piece of art/literature/drama can be a source of Rasa and Rasabhasa both in the context of LGBT plays for different individuals with different sexual inclination and members of completely different society. When one steps into the shoes of a character to experience Rasa, the difference lies between whether we sympathize (relate) or empathize.

At the same time, a question raises that - whether Rasa is gender neutral or not, the answer is - Rasa has not been discussed in the light of gender by any of the Indian theorists or scholars so far, which indicates that Rasa is gender neutral for male and Female, two genders of the Natyashastriya era. An investigation of Rasa in these plays answers that all Rasa can be gender neutral except Shringara Rasa. In the depiction of Shringara Rasa, Alambanavibhava that means the absence of male and female protagonist cannot be ignored. Indian citizens, an audience of multifarious web series of different languages, cultures, traditions, and characters may accept LGBT community, may accept plays or any literature based on the life of LGBT community but relish of Shringara Rasa is not possible because it is not relatable or cannot be empathies with the character. In such situations, ShringaraRasa relishes only when one is unaware of the sexuality of the LGBT character, but when the truth reveals it gets converted in Hasya Rasa orRasabhasa.

i.e. -

"Ed: (disappointed) Oh.

Kiran: It-it's my fault.

Kiran: I don't want to be fussy, Ed.

Ed: Baby, please be fussy. I like you when you are fussy.

$$
\cdots
$$

$\cdots$

Ed: (pats her cheek) Relax, I can take care of you. (Exits)" (Dattani, 2000, P.52) 
One may sympathize with Kiran and Ed at the beginning of the play, unaware of Ed's truth, as a result of which at a glance that appears to be Shringara Rasa is actually Rasabhasa or vice versain the context of On a Muggy Night in Mumbai, Homosexual theme based plays.

In the framework of other Rasa, presence of unconventional protagonist (LGBT) may not matter because of an acceptance of LGBT community as part of society; being an audience, one can experience Karuna Rasa just by observing their suffering, when Bunny, a successful TV actor (as an ideal father and a husband), accepts heterosexuality for gaining respect from the society.

i.e. -

"Bunny: I know. Just as the man whom my wife loves does not exist. I have denied a lot of things. The only people who know me-the real me-are present here in this room. And you all hate me for being such a hypocrite. .......... And I continue to lie to millions of people every week on Thursday nights. There's no such person..." (Dattani, 2000, P.102-103)

Karuna Rasa can also be experienced, when Anarkali, a head of hijra, shares her experience and unravels a tale of Kamla's suffering.

i.e. -

“Anarkali: Would you have believed me? ... ... So many times I warned her. ... ... I fought with her. I scratched her face, hoping she will become ugly and Subbu will forget her. ... ... I told her to run. ......" (Dattani, 2000, P.41)

Hasya Rasa also relishes, through the presence of Sharad's character and his gestures and dialogue delivery, which creates more impactbecause of his homosexuality, following a principle of performativity. On the other hand, the other kind of individual may consider the same as an insulting statements for heterosexuals and may it be a source of Raudra Rasa. i.e. -

"Sharad: Oh, my Gawd! Those heterosexuals are at it again!

Kamlesh: If you can see them, they can see us. ...

Sharad: Are you crazy? Just look at them! Yeech! That guy is just bad news.

Kamlesh: ...

Sharad: Of course he is her husband! He is too fat and bald to be her lover." (Dattani, 2000, P.53)

Modern drama have absolutelydissimilar themes than ancient ones, based on realistic incidents/events in the life of the any kind of person of the society, be it rich or poor, heterosexual or homosexual. Modern drama hardly deals with the themes of war or fight, in that case, until and unless, one is a policemen or an army officer cannot be an exponent of 
Veera Rasa. When in the modern drama, one fights verbally or may be raises voice against society for own rights or truth or justice, can also relish Veera Rasa, a fight of Champa and Anarkali for their rights the marriage of Subbu, a son of the Minister, is such an instance. i.e. -

"Champa: May God bless this house with many children!

Anarkali: May God always smile upon this house!

$\cdots$

Champa: Do not be so angry, sir. It is a happy occasion.

Champa: Thank you, sir, but we must sing and dance to bless this house and the handsome couple." (Dattani, 2000, P.38-39)

Propriety or Impropriety is contextual, in very near history when lesbian and gay marriages were not legally permissible in Indian society but were acceptable in the other parts of the world, even today, there are countries, where it is still not legal/ acceptable. Technological advancements have converted the world into a global village, it is an era of translation, it is a time of world literature, and it is a time of web series, nothing is limited to a place, region, country or a continent due to which humans of a specific place/continent are exposed to others' beliefs, traditions, culture and customs, which is one of the reasons behind accepting LGBT. There is a huge difference between accepting and adapting something and Rasa experience is based on adaptation not acceptation.

\section{Conclusion}

It is alleged that, if something is required to be followed by the society, either it needs to be legalized or religionised, as part of which LGBT has been legalized in India under the section 377 of Indian Penal Code on $6^{\text {th }}$ September 2018. When it comes to aesthetic experience, Rasa or Rasabhasa in the context of thecontemporary and permissive society, whichis ready to accept homosexuality as part of society and literature, due to which such homosexual characters can also be a charioteer of Rasa. Another possibility, especially in the context of Shringara Rasa is that the homosexual or transgender, whose sexual orientation is different, watches plays with romantic dialogues among homosexuals, he would experience Shringara Rasa but when a person with heterosexual inclination watches such plays the experience that relishes is not Rasa but Rasabhasa or HasyaRasa or Bibhatsa Rasa. Due to the experience of 
Rasabhasa or Hasya Rasa, it appears to be a black comedy but at the same time it's a story of certain individuals who experience the same.

Through a detailed study of On a Muggy Night in Mumbai and Seven Steps around the Fire, a conclusion can be drawn that the modern Indian English drama cannot be an exponent of only one Rasa for the diversified audience of the present world, encountering number of various performances by different drama companies in different regions or through different mediums such as - street plays, theatrical performances, Television performances, etc, unlike the ancient Indian drama.Individuals from diverse group may experience different Rasa or Rasabhasa from the very same drama or the scene or a line, based on their associations, psyche, understanding, experience, etc. Thus, a theory of Rasa and Rasabhasa is relevant in the modern Indian drama but needs to be modified or certain new insights need to be drawn to make it more relevant in the present world.

\section{Acknowledgement}

We would like to thank all the anonymous reviewers of this article for providing their valuable comments and suggestions. 
Towards Excellence: An Indexed, Refereed \& Peer Reviewed Journal of Higher Education / Dr. Anshu Surve \& Ms. Garima Tiwari / Page 526-543

\section{References}

Agarwal, Beena. Mahesh Dattani's Plays: a New Horizon in Indian Theatre. Book Enclave, 2015 .

Agnipurana of MaharsiVedavyasa.Chowkhamba Sanskrit Series Office, 1966.

Barlingay, S. S. (1981). “What Did Bharata Mean by Rasa?’.Indian Philosophical Quarterly.

"Book Review: 'Seven Steps Around the Fire' by Mahesh Dattani." ELTWeekly, 28 Dec. 2013, eltweekly.com/2013/12/book-review-seven-steps-around-the-fire-by-maheshdattani/.

Butler, Judith. Gender Trouble: Feminism and the Subversion of Identity. Routledge, Taylor \& Francis Group, 2015.

Dattani, Mahesh. Collected Plays.Penguin Books, 2000.

Dattani, Mahesh. Collected Plays.Penguin, 2005.

Dhanamjaya , and Haas Georg C O. The Daśarüpa: a Treatise on Hindu Dramaturgy by Dhanamjaya. 1912.

Dhavan, R. K., \& Reddy, V. K. Flowering of Indian Drama: Growth and Development. Prestige, 2004.

Dhawan, R. K. Recent Indian Drama in English.Prestige Books, 2010.

Dhawan, R. K., and Tanu Pant.The Plays of Mahesh Dattani: a Critical Response. Prestige Books International, 2018.

Muni, Bharata, et al. Natyashastra.Banaras Hindu University, 1971.

Nagendra.Rasa-siddhānta.NeśanalaPabliśingaKampan̄̄, 2019.

Nair, Sreenath. The Natyasastra and the Body in Performance: Essays on Indian Theories of Dance and Drama. McFarland, 2015.

Patnaik, Priyadarshi. Rasa in Aesthetics. D.K. Printworld, 2002.

\section{Dr. Anshu Surve}

Assistant Professor, Department of English The Maharaja Sayajirao University of Baroda, Vaodara 
Towards Excellence: An Indexed, Refereed \& Peer Reviewed Journal of Higher Education /

Dr. Anshu Surve \& Ms. Garima Tiwari / Page 526-543

Email: anshu.surve-eng@msubaroda.ac.in

$\boldsymbol{\&}$

Ms. Garima Hariniwas Tiwari

Research Scholar

Department of English

The Maharaja Sayajirao University of Baroda, Vadodara

Email: garima.tiwari-eng@msubaroda.ac.in 